\title{
DOE/FE/633/3--T/
}

\section{South Korean Energy Outlook: Coal and Electricity Focus}

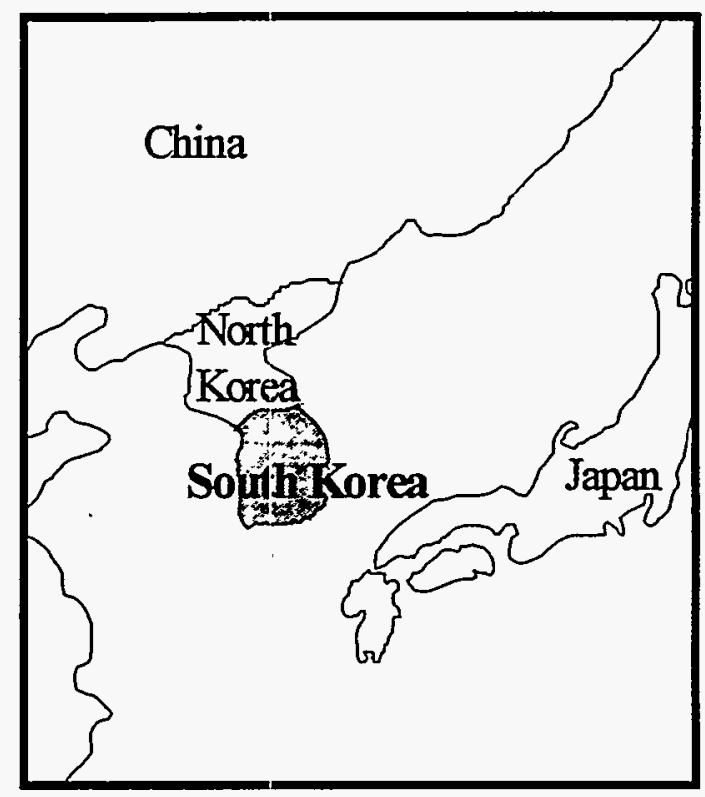

\author{
Coal Project \\ Program on Resources: Energy and Minerals \\ East-West Center \\ 1777 East-West Road \\ Honolulu, Hawaii 96848
}

Tel: (808) 944-7550

Fax: (808) 944-7559

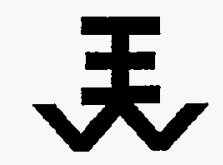

March 1995

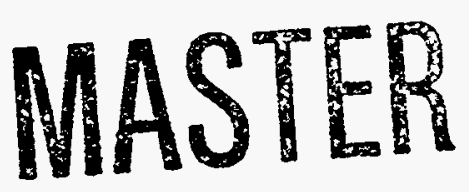

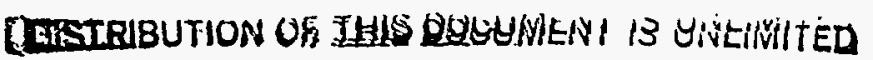

This report was prepared as part of the Coal Project, Program of Resources: Energy and Minerals by

Dr. Charles J. Johnson, Head of the Coal Project, Dr. Binsheng Li, Project Fellow, and Ms. Amy J.

Lamke, Visiting Fellow. This report was edited by Ms. Ellen M. Young.

The U.S. Department of Energy, Office of Fossil Energy provided financial support for the preparation of this report. The views in this report are those of the authors, and not necessarily those of the Department of Energy or of the East-West Center. 


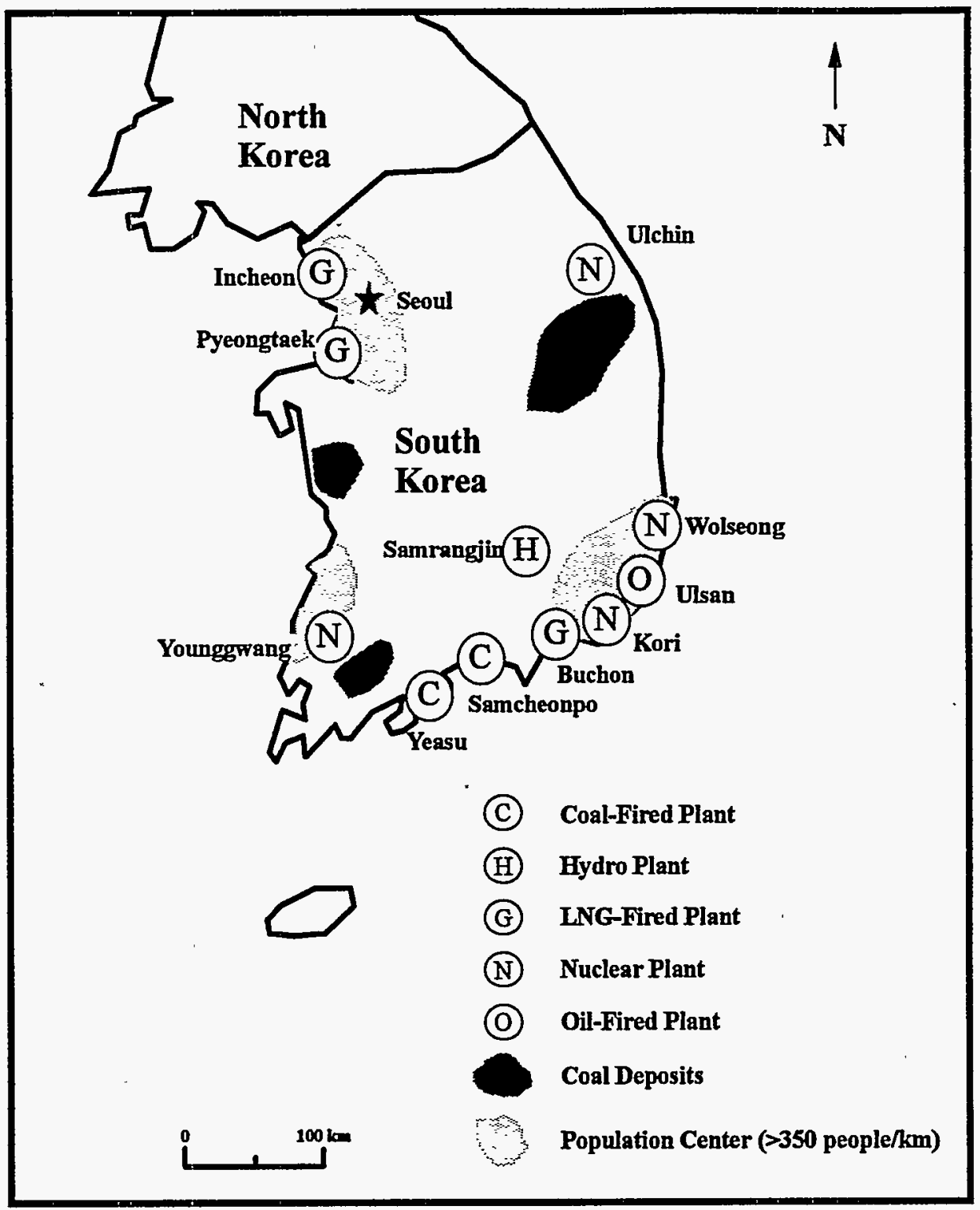




\section{DISCLAIMER}

This report was prepared as an account of work sponsored by an agency of the United States Government. Neither the United States Government nor any agency thereof, nor any of their employees, make any warranty, express or implied, or assumes any legal liability or responsibility for the accuracy, completeness, or usefulness of any information, apparatus, product, or process disclosed, or represents that its use would not infringe privately owned rights. Reference herein to any specific commercial product, process, or service by trade name, trademark, manufacturer, or otherwise does not necessarily constitute or imply its endorsement, recommendation, or favoring by the United. States Government or any agency thereof. The views and opinions of authors expressed herein do not necessarily state or reflect those of the United States Government or any agency thereof. 


\section{DISCLAIMER}

Portions of this document may be illegible in electronic image products. Images are produced from the best available original document. 


\section{EXECUTIVE SUMMARY}

- From 1981 to 1993, the Republic of Korea (Korea) had the third highest energy growth rate and the second highest GDP growth rate in Asia.

- The demand for electricity is projected to increase at an average of 7.2 percent per year to 2000 and average 4.5 percent per year from 2001 to 2015.

- Korea is projected to account for the largest increase in imported coal (44 million tons) among Asian countries from 1995 to 2015.

- Bituminous coal consumption is projected to increase from 33 million tons in 1994 to 80 million tons in 2015.

- Planned $\mathrm{SO}_{2}$ emission limits for the late1990 s will result in the installation of desulfurization technologies on new coalfired power plants.

- Coal-fired generating capacity is projected to increase from $5.8 \mathrm{GW}$ in 1993 to 11.6 $\mathrm{GW}$ in 2000 and $24.2 \mathrm{GW}$ in 2015.

- High cost production of domestic anthracite will fall to less than five million tons by 2000.

- Nuclear power is projected to continue to account for the largest share of electricity generation over the 1995-2015 period.

- Opportunities for private participation are developing in the power sector; however, near term opportunities may be limited, and above average returns on investments are expected to be difficult to achieve.

- Korea's strategy to have diversified energy sources and equity participation in coal mines is expected to continue, but will increasingly be guided by market forces.
Korea had Asia's second highest GDP growth rate, averaging 8.5 percent per year over the 1981-1993 period shown in Figure 1. Korea's export orientation, political stability, favorable business environment, and large investments in human capital all contributed to this high economic growth rate.

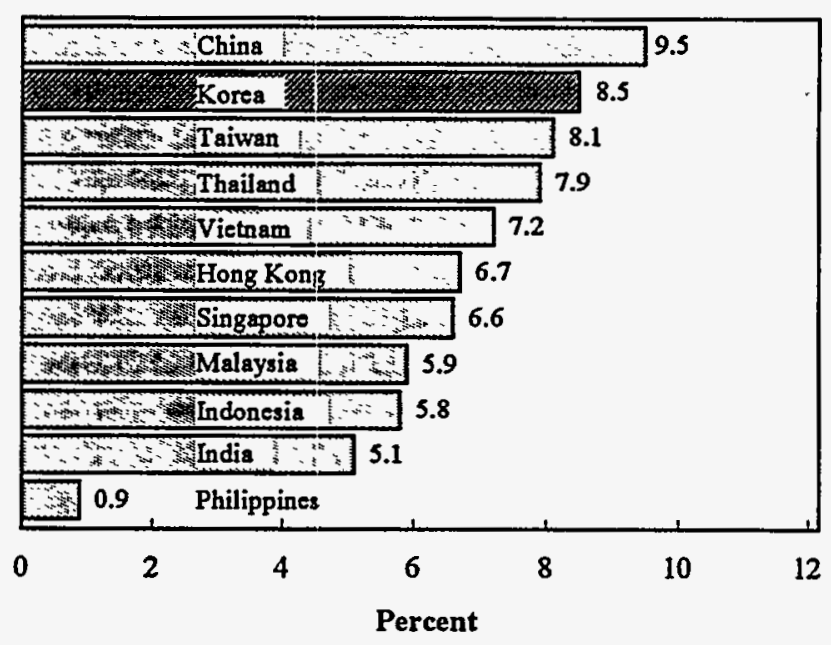

Figure 1. GDP Growth Rates for Selected Asian Economies (1981-1993)

During the early 1990s, Korea's GDP growth rate decreased to less than 5 percent per year; however, recent government policy reforms are expected to boost GDP growth rates to the 5-7 percent per year range during the later half of the 1990s. Beyond 2000, GDP growth rates are projected to range from 4-5 percent per year.

An important long term consideration not examined in this report is the impact of future closer economic ties with North Korea, and perhaps the reunification of North and South Korea. At a minimum, closer economic ties should be anticipated. Therefore, the size of the long term energy market available through South Korea might be much larger than the projections in this report. The moderate distance of 200 kilometers between the capitals

\section{ECONOMY}


of North and South Korea (and their population centers) suggests interconnection of the two electricity systems may have economic merit in the long term.

\section{ENERGY SECTOR ORGANIZATION}

- The Ministry of Trade, Industry and Energy (MOT) is Korea's key energy planning agency.

- The Korean Electric Power Corporation (KEPCO) is a state-owned power corporation responsible for Korea's electricity generation, transmission, and distribution.

- The Ministry of Science and Technology (MOST) licenses, regulates, and supervises the nuclear industry, but KEPCO retains the responsibility for nuclear power plant procurement, construction, and operation.

- The Korea Gas Corporation (KGC), a stateowned corporation, operates the receiving terminal for liquefied natural gas (LNG) and transports gas to KEPCO and to private town gas companies. According to the Korean government, additional companies may be allowed to import LNG in the near future. Korea's oil refineries are now controlled by five firms, and this sector is scheduled to be gradually opened to new firms.

- The Korea Institute of Energy Research (KIER) is responsible for the advancement of energy and mineral technology, and the collection and preparation of energy data.

- The Korea Energy Economics Institute (KEEI) prepares the annual report "Korea Energy Outlook" and undertakes a range of economic analyses of energy issues in Korea.

\section{ENERGY POLICIES}

The increase in petroleum prices in the 1970s resulted in government policies to diversify away from heavy dependence on petroleum, and to establish multiple sources of energy supplies.
The two largest beneficiaries of these policies have been Korea's programs for nuclear and coal-fired power plants.

The Korean government has a long term goal to have domestic companies hold equity in mines supplying 30 percent of coal imports. However, over the past decade, Korean companies have held equity in overseas mines accounting for a relatively constant 9 percent of import needs. Foreign equity participation exists in mines in Australia, Canada, and the United States, with substantial low quality coal holdings in Indonesia.

The Korean government is likely to reduce its present 78 percent ownership in KEPCO to under 70 percent in the next few years. In addition, the government is opening the power sector to various forms of private sector participation (see Private Sector Opportunities).

The "Support for Communities Surrounding Power Plants Act" was enacted in 1980 to promote understanding and cooperation between local communities and power plants. By the end of 1993 KEPCO had spent $\$ 68$ million for cooperation activities, including installing public facilities and subsidizing education. Foreign investors in power plants will need to include provisions for financial support to local communities for all future power plant developments.

\section{ENERGY OVERVIEW}

Figure 2 shows that during the 1981-1985 period, energy consumption in Korea grew at 5.1 percent per year, then doubled to 10.6 percent per year from 1986 to 1993 . This figure also shows that the energy consumption growth rate is projected to decrease to 6.1 percent 
between 1994 and 2000, and then average 3.2 percent per year between 2001 and $2015^{1}$

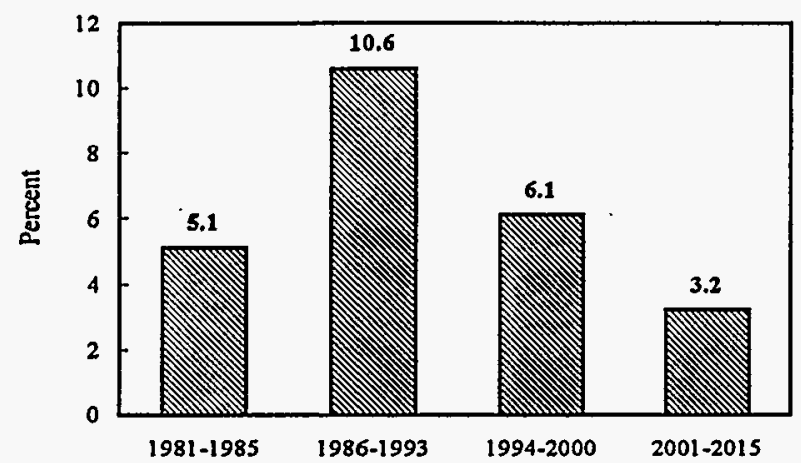

Figure 2. Energy Consumption Growth Rates

Figure 3 shows the estimated energy mix for 1994 and the projected energy mix for 2000 and 2015. In 1994, the energy mix consisted of oil-63 percent, coal-20 percent, nuclear-11 percent, LNG -5 percent, hydro and other renewables -2 percent. The energy sources projected to have the highest annual growth rate in the medium term (1994-2000) are LNG at 8.3 percent and nuclear at 7.6 percent.

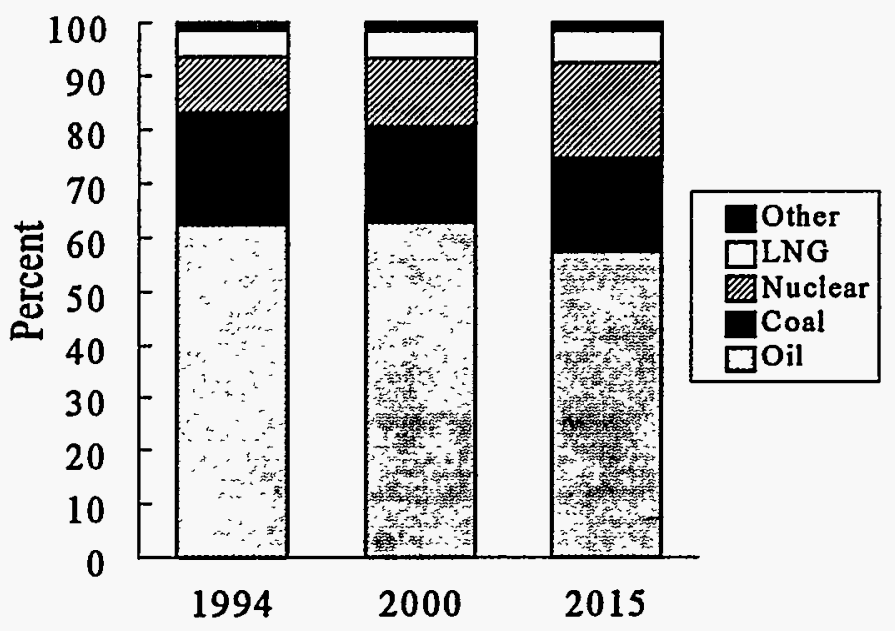

Figure 3. Primary Energy Consumption Mix in the Korean Economy: 1994-2015

\footnotetext{
' The high elasticity of energy to GDP growth rates is declining rapidly toward 1.0. Both GDP and energy consumption are projected to grow at an average of about 6.0 percent per year over the $1994-2000$ period (elasticity $=1.0$ ).
}

Korea's 95 percent dependence on energy imports results in substantial weight given to strategic considerations. Korea follows a policy of diversified energy types and diversified sources of supply. However, increasingly, the trend is toward market forces (price) determining coal supplies.

\section{ENERGY RESERVES AND COAL PRODUCTION}

South Korea has modest reserves of about 200 million tons of anthracite coal, and $3 \mathrm{GW}$ of largely developed hydropower. The removal of government assistance to the high cost anthracite industry in the late 1980 s resulted in a rapid decline in production from 24.8 million tons in 1988 to 9.4 million tons in 1993. Anthracite production in the future is speculative, with a plausible scenario of 3-5 million tons in 2000 and $1-3$ millions tons by 2010. Three quarters of the existing 40 anthracite mines in Korea are projected to cease operation within a few years (Kim Il-Kwang, 1994).

Note that North Korea apparently has large reserves of anthracite and produces at least 30 million tons per year, and, according to some sources, much more. It is speculated that much of the North Korean production is high cost and would not be competitive in a market economy.

\section{COAL CONSUMPTION}

Korea's large, rapidly-growing bituminous coal demand is met entirely by imports. During the next 15 years Korea is projected to account for the largest increase in coal imports of any Asian country. As shown in Table 1, bituminous coal consumption jumped from 5 million tons per year in 1980 to 33 million tons in 1993, and is projected to reach 48 million tons by 2000 and 80 million tons by 2015 . Table 1 also shows that all sectors, with the exception of the residential sector, have increased coal 
consumptions over the 1980-1993 period. Anthracite consumption, primarily in the residential sector, has been declining by more than 20 percent per year in recent years. Anthracite consumption decreased by about 50 percent from 1980-1993, primarily because of the shrinking residential and commercial market.

Table 1. Coal Consumption by Sector (Million metric tons)

\begin{tabular}{|c|c|c|c|c|}
\hline & 1980 & 1993 & $2000^{*}$ & $2015^{*}$ \\
\hline \multicolumn{5}{|l|}{ Anthracite } \\
\hline $\begin{array}{l}\text { Residential \& } \\
\text { Commercial }\end{array}$ & 18.0 & 7.7 & 1.3 & 0.1 \\
\hline $\begin{array}{l}\text { Commercial } \\
\text { Electricity }\end{array}$ & 1.6 & 2.3 & 2.2 & 2.0 \\
\hline Others & 0.9 & 0.1 & 0.2 & 0.2 \\
\hline Total Anthracite & 20.5 & 10.1 & 3.7 & 2.3 \\
\hline \multicolumn{5}{|l|}{ Bituminous } \\
\hline Iron \& Steel & 4.0 & 16.0 & 15.6 & 15.5 \\
\hline Electricity & 0.0 & 10.3 & 25.0 & 55.0 \\
\hline Cement \& Others & 1.0 & 6.6 & 7.8 & 9.2 \\
\hline Total Bituminous & 5.0 & 32.9 & 48.4 & 79.7 \\
\hline \multicolumn{5}{|c|}{ Total Coal Consumption } \\
\hline \begin{tabular}{|l} 
Residential \& \\
Commercial
\end{tabular} & 18.0 & 7.7 & 1.3 & 0.1 \\
\hline Iron \& Steel & 4.0 & 16.0 & 15.6 & 15.5 \\
\hline Electricity & 1.6 & 12.6 & 27.2 & 57.0 \\
\hline Cement \& Others. & 1.9 & 6.7 & 8.0 & 9.4 \\
\hline Total & 25.5 & 43.0 & 52.1 & 82.0 \\
\hline
\end{tabular}

*Projections by the EWC Coal Project

Sources: Major Statistics of Korean Economy 1994; Korea Energy Review Monthly, March 1994; KEEI; KEPCO; and the MOT.

In 1994, thermal coal accounted for about 54 percent of coal imports. By 2015, thermal coal is projected to increase its share to about 80 percent of total coal imports. In 1994, Australia, Canada, and the United States accounted for two thirds of Korea's coal imports. The trend in imports is for increasing imports from Asia and
Australia and a declining share of imports from North America - particularly higher priced U.S. supplies. Increased supplies are planned from low cost suppliers in Indonesia and South Africa, which may adversely influence Australia's share of Korea's imports in the 1990s.

\section{ELECTRICITY SECTOR}

During the 1980-1993 period, electricity consumption grew at an average of 11 percent per year-almost one-third faster than the GDP growth rate of 8.5 percent per year. The growth in electricity consumption jumped almost one-third to 14.2 percent in 1994 and is projected to increase by 9 percent in 1995 (KEEI, 1995). In response to the higher than expected growth rate in electricity consumption, MOT has revised its projections of peak capacity from $36 \mathrm{GW}$ to $41 \mathrm{GW}$ in 2000 . These high growth rates are projected to decline substantially by 1996 or 1997 . The growth rate in electricity generation is projected to average 7.2 percent per year between 1994 and 2000 , and 4.5 percent per year between 2000 and 2015 .

Figure 4 shows major changes occurring in the energy mix of electricity generation from 1980 to 2015. During the 19801993 period, nuclear's share of generation grew from 9 percent to 40 percent, followed by coal, which increased from 7 to 21 percent. The LNG market developed after 1985, and accounted for 10 percent of total generation in 1993. Oil's share decreased by two-thirds from 79 percent in 1980 to 24 percent in 1993.

Between 1993 and 2015, increasing shares of generation are projected for nuclear (40 percent to 48 percent) and coal ( 21 percent to 34 
percent), with oil's share declining from 24 percent to 4 percent.

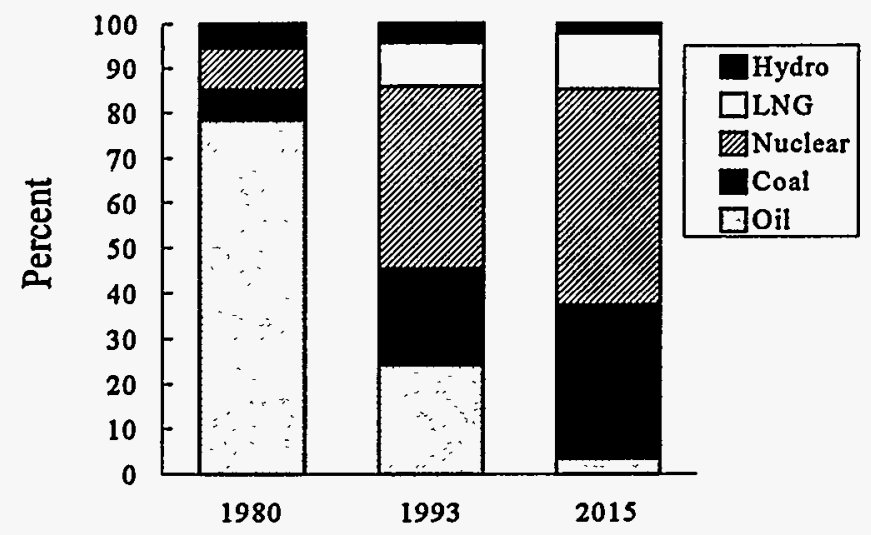

Figure 4. Electricity Generation Mix: 19801993

Figure 5 shows the growth in plant capacity from 1980 to 1993 with projections to 2015. As shown in the figure, plant capacity tripled from 9 GW in 1980 to $28 \mathrm{GW}$ in 1993. Capacity is projected to almost triple again from 1993 to 2015 , to reach $81 \mathrm{GW}$ in 2015.

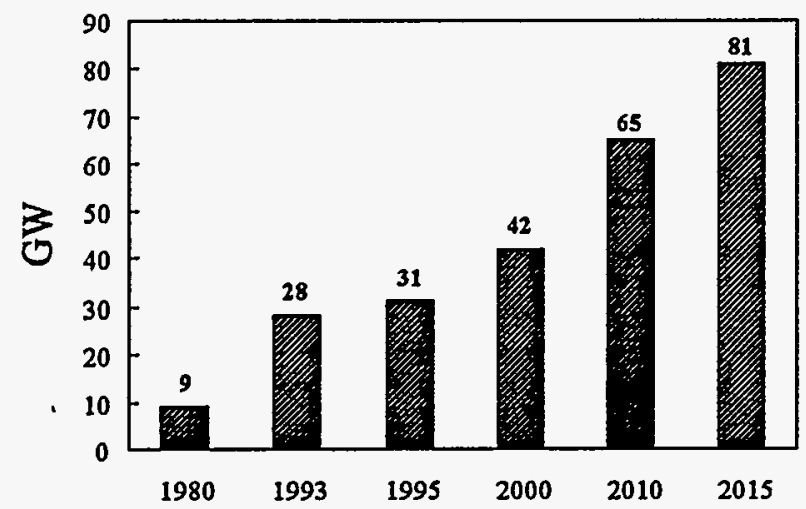

Figure 5. Installed Capacity: 1980-2015

\section{Nuclear Power Capacity}

As shown in Table 2, by the end of 1993, KEPCO's nuclear capacity reached $7.6 \mathrm{GW}$ (27.5 percent of installed capacity). Construction currently underway will almost double nuclear capacity to $13.7 \mathrm{GW}$ by 2000 . By 2015 , nuclear capacity is projected to reach $31 \mathrm{GW}$. Korea is projected to maintain its second place position in nuclear capacity in Asia (Japan is first) to at least 2010.

Table 2. Installed Capacity by Fuel Type (GW)

\begin{tabular}{||c|c|c|c|c|c|c||}
\hline Year & Nuclear & Coal & Hydro & Oil & LNG & Total \\
\hline 1980 & 0.6 & 0.7 & 1.2 & 6.9 & 0 & 9.4 \\
1985 & 2.9 & 3.7 & 2.2 & 7.4 & 0 & 16.1 \\
1990 & 7.6 & 3.7 & 2.3 & 4.8 & 2.6 & 21.0 \\
1993 & 7.6 & 5.8 & 2.5 & 5.6 & 6.2 & 27.7 \\
$1995^{*}$ & 8.6 & 7.3 & 3.1 & 6.9 & 5.2 & 31.1 \\
$2000^{*}$ & 13.7 & 11.7 & 3.9 & 5.7 & 7.2 & 42.1 \\
$2010^{*}$ & 24.5 & 19.4 & 6.6 & 3.0 & 11.4 & 64.9 \\
$2015^{*}$ & 30.7 & 24.2 & 8.0 & 3.0 & 15.3 & 81.2 \\
\hline
\end{tabular}

*Projections by the EWC Coal Project

Sources: Major Statistics of Korean Economy 1994;

Korea Energy Review Monthly, March 1994; KEEI;

KEPCO; and MOT.

\section{Coal-Fired Capacity}

The long term strategic policy goal is to increase coal-fired capacity to 30 percent. Between 1993 and 2006, 27 new coal-fired power plants are planned with a total capacity of $13.6 \mathrm{GW}$. Table 2 shows installed coal-fired capacity increasing from $5.8 \mathrm{GW}$ in 1993 to $24 \mathrm{GW}$ in 2015. Coal faces a number of uncertainties that may delay some capacity additions, including finding appropriate plant sites and meeting increasingly stringent environmental regulations (see Environmental Policies and Regulations). At present, six of the nine new plant sites have been secured.

\section{LNG-Fired Capacity}

The power sector is the dominant user of $L N G$, accounting for 57 percent of total LNG consumption in 1993. The Korean government projects that LNG's share of the power generation market will decrease to less than $\mathbf{5 0}$ percent by 2000 .

At the end of 1993, KEPCO's LNG-fired capacity stood at $6.2 \mathrm{GW}$ and accounted for 22.4 percent of installed capacity. The combination of continued growth in electricity demand, more 
stringent environmental regulations, and the need for peak-load capacity will result in LNG capacity growing to about $15 \mathrm{GW}$ by 2015 . The installation of LNG-fired combined cycle power plants has allowed KEPCO to achieve very high thermal efficiencies of almost 50 percent and to supply district heating in connection with the government's "New Town Development Plan."

The possibility of pipeline gas from the Sakahalin gas fields (about 3000 kilometers to the north of Seoul, in the Russian Far East) has been suggested by Khartukov (1994) and others; however, such a pipeline interconnection with Korea is unlikely before 2010 at the earliest.

\section{Pumped Storage Capacity}

As previously noted, hydroelectric capacity is largely committed. However, KEPCO plans 3 GW of pumped storage capacity for the 1993 to 2006 period. The 19 planned pumped storage facilities are necessary to make use of off-peak electricity from its nuclear power plants. The combination of conventional hydro and pumped storage capacity is projected to increase from $2.5 \mathrm{GW}$ in 1993 to $8.0 \mathrm{GW}$ in 2015 , as shown in Table 2. However, long term projections of pumped storage capacity are speculative.

\section{Oil-Fired Capacity}

Strictly oil-fired capacity is projected to gradually decline from $5.6 \mathrm{GW}$ in 1993 to $3 \mathrm{GW}$ in 2015. In the intermediate term from 1993 to 2006, KEPCO plans to add about $500 \mathrm{MW}$ of oil-fired capacity.

Although the role of oil in the power sector is likely to continue to decline, it should be noted that coal-fired power plants are dual-fired and could substitute oil if price and environmental conditions warrant. A larger than projected role for oil is more likely over the next decade but unlikely after 2005

\section{THERMAL AND METALLURGICAL COAL PRICES}

Figure 6 shows the average c.i.f. cost of imported thermal and metallurgical coals to Korea from 1985 to 1994 . In 1994, the average c.i.f. prices of both thermal and metallurgical coal were at their lowest point since Korea became a significant coal importer in the early 1980s.

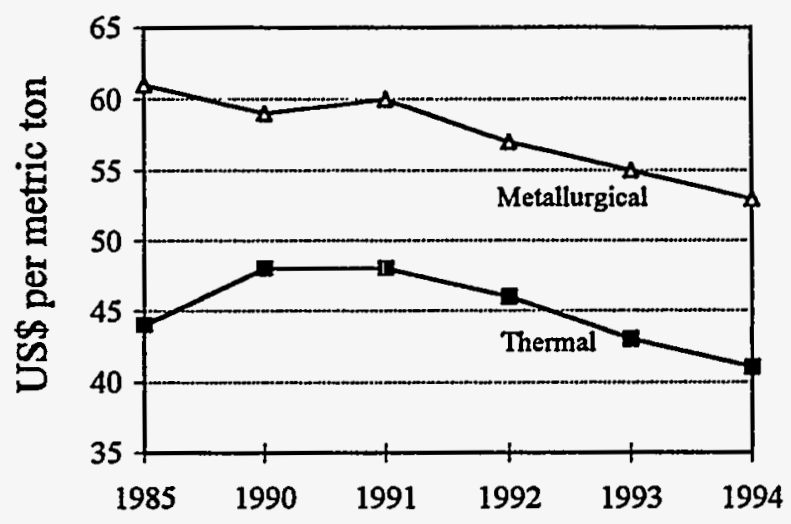

Figure 6. Imported Coal Prices (c.i.f.)

Thermal and metallurgical coal prices have been declining because of the combination of an increased share of imports from lower cost producers and the general decline in international coal prices. High cost coal imports from the United States declined the most from 1985 to 1993, with metallurgical coal imports declining from 26 to 13 percent and thermal coal imports declining from 7 to 5 percent.

\section{ELECTRICITY PRICES}

Electricity prices in local currency (won) increased at an average annual growth rate of 2.7 percent for lighting and 0.7 percent for others between 1980 and 1993. In U.S. dollars, the lighting tariff increased from $\$ 0.09$ per KWh in 1980 to $\$ 0.10$ per KWh in 1993 . The tariff to industrial customers declined from $\$ 0.075$ per KWh in 1980 to $\$ 0.067$ per KWh in 1993. The overall average electricity price decreased from $\$ 0.077$ per KWh in 1980 to $\$ 0.073$ per KWh in 
1993. If inflation is included, electricity costs decreased between 1980 and 1993 in both local currency and in U.S. dollars. With respect to electricity prices, KEPCO is permitted to recover its operating costs plus a fair return on capital. Rate hikes must be approved by the MOT, then the Price Stabilization Committee, the Economic Planning Board, and the cabinet. This complex rate setting system introduces broader economic and political factors into the rate setting process, and, consequently, can lead to less timely rate increases.

\section{ENVIRONMENTAL POLICIES AND REGULATIONS}

As shown in Table 3, until the end of 1994, Korea's standards for coal-fired power plant emissions limited $\mathrm{S}_{2} \mathrm{O}_{2}$ to $700 \mathrm{ppm}$ (1.63 $\mathrm{lb} / \mathrm{MBtu}), \mathrm{NO}_{x}$ to $350 \mathrm{ppm}(0.59 \mathrm{lb} / \mathrm{MBtu})$, and particulates to $250 \mathrm{mg} / \mathrm{m}^{3}(0.2 \mathrm{lb} / \mathrm{MBtu})$. From January 1995 to December 1998, emissions of $\mathrm{SO}_{2}$ will be limited to $500 \mathrm{ppm}$ (1.16 $\mathrm{lb} / \mathrm{MBtu}$ - - equivalent to about 0.7 percent sulfur coal. During that same period, the emissions of particulates will be limited to 100 $200 \mathrm{mg} / \mathrm{m}^{3}(0.08-0.16 \mathrm{lb} / \mathrm{MBtu})$.

Table 3. Emission Limits for Power Plants

\begin{tabular}{|l|c|c|c|}
\hline Emission Type & Until 12/94 & $1 / 95-12 / 98$ & After 1/99 \\
\hline SO ${ }_{\mathrm{x}}(\mathrm{ppm})$ & & & \\
Anthracite (Local) & $1,200-1,650$ & $1,200-1,650$ & 270 \\
Bituminous Coal & 700 & 500 & 270 \\
\hline $\mathrm{NO}_{\mathrm{x}}$ (ppm) & 350 & 350 & 350 \\
$\mathrm{All} \mathrm{Coal}$ & & & \\
\hline Particulates (mg/m & & 100 & 50 \\
$>30,000 \mathrm{~m}^{3} / \mathrm{hr}$ & 250 & 150 & 50 \\
$6,001-30,000 \mathrm{~m} / \mathrm{hr}$ & 250 & 200 & 150 \\
\hline$<6,000 \mathrm{~m}^{3} / \mathrm{hr}$ & 300 & 2 & \\
\hline
\end{tabular}

Source: Summarized from the Prime Minister's

Decree on the Air Quality Protection Law, 1992.
After January 1999, $\mathrm{SO}_{2}$ emissions standards will be further tightened to $270 \mathrm{ppm}(0.63$ $\mathrm{lb} / \mathrm{MBtu}$ ), which is equivalent to approximately 0.4 percent sulfur coal; particulate emissions will be limited to $50-150 \quad \mathrm{mg} / \mathrm{m}^{3} \quad(0.04-0.12$ $\mathrm{lb} / \mathrm{MBtu})$. Because internationally traded coal in the Asian region typically contains between 0.5 and 0.8 percent sulfur, current $\mathrm{SO}_{2}$ regulations can be met with available low sulfur coals. However, sulfur control equipment will have to be installed by 1999 at the latest to meet the 270 ppm limit on $\mathrm{SO}_{2}$ emissions. Figure 7 shows the sulfur content in coal that will meet the limits of $\mathrm{SO}_{2}$ in pounds per $\mathrm{MBtu}$ and milligrams of $\mathrm{SO}_{2}$ per cubic meter.

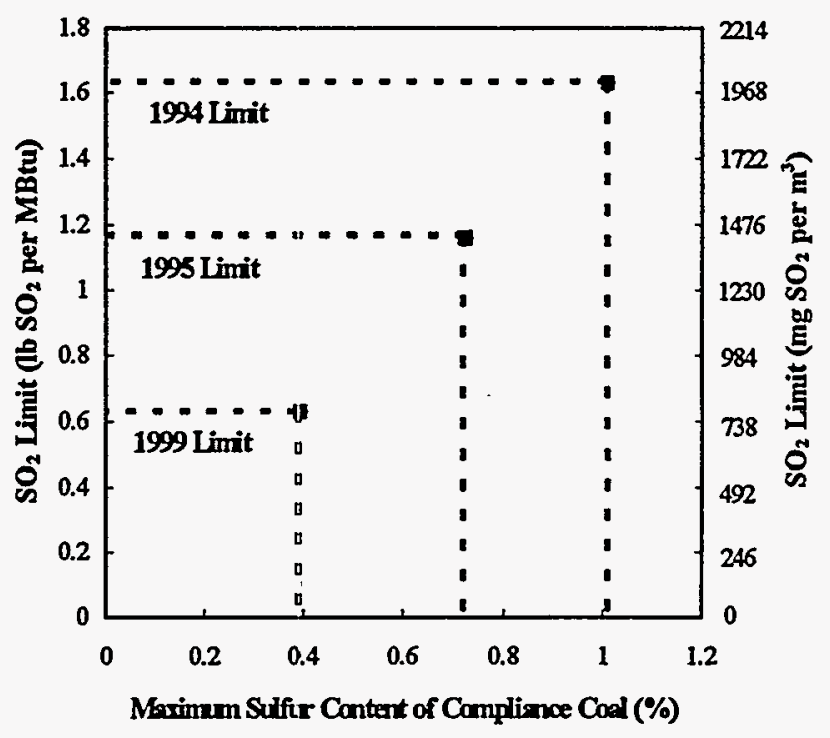

Figure 7. Sulfur Content in Coal vs. Limits of $\mathrm{SO}_{2}$ per MBtu

KEPCO's coal-fired plants have electrostatic precipitators that maintain average particulate emissions to no more than 100 to $150 \mathrm{mg} / \mathrm{m}^{3}$. $\mathrm{NO}_{x}$ emissions are controlled by using low $\mathrm{NO}_{x}$ burners and two stage combustion. At present, Korea has no regulations restricting $\mathrm{CO}_{2}$ emissions.

Table 4 shows the average sulfur contents of coal in Korea in 1991. It is probable that the 
average sulfur content of coal consumed in the power sector has declined since 1991.

Table 4. Average Sulfur Content of Coal in Korea in 1991

\begin{tabular}{|l|c|}
\hline Sector & Percent Sulfur \\
\hline Anthracite & 0.55 \\
Metallurgical & 0.59 \\
Thermal & \\
Power & 0.70 \\
Cement & 1.00 \\
Other & 0.65 \\
\hline
\end{tabular}

Source: Kim Il-Kwang, 1994.

Table 5 shows the estimated $\mathrm{SO}_{2}, \mathrm{NO}_{\mathrm{x}}$, and $\mathrm{CO}_{2}$ emissions in Korea in 1993. Coal accounts for about one-third of $\mathrm{SO}_{2}$ and $\mathrm{CO}_{2}$ emissions and one-sixth of the $\mathrm{NO}_{\mathrm{x}}$ emissions.

Table 5. Estimated Emissions in Korea: 1993 (million tons per year)

\begin{tabular}{|l|c|c|c|}
\hline Emission & Total & Coal & Coal's Share (\%) \\
\hline $\mathrm{SO}_{2}$ & 1.9 & 0.61 & 33 \\
\hline $\mathrm{NO}_{\mathrm{x}}$ & 1.2 & 0.23 & 18 \\
\hline $\mathrm{CO}_{2}$ & 93.3 & 29.5 & 32 \\
\hline
\end{tabular}

\section{CLEAN COAL TECHNOLOGIES}

KEPCO presently uses low- $\mathrm{NO}_{\mathrm{x}}$ burners in its coal-fired power plants, and can meet $\mathrm{NO}_{\mathrm{x}}$ emission limits during the 1990s. As shown in Table 3, emission limits for $\mathrm{SO}_{2}$ emissions are being tightened in three stages in the 1990s. KEPCO is following a least cost course to met successively tighter $\mathrm{SO}_{2}$ emission standards. As previously discussed in Environmental Policies and Regulations, sulfur control technology will be needed to meet emission limits in 1999 . Compliance coal to meet 1999 emission regulations would have to have a sulfur content of 0.4 percent or less. Although some coal traded in Asia can meet the $1999 \mathrm{SO}_{2}$ limits, the strategic goal of diversified sources of supply is unlikely to be met by reliance on limited sources of such low sulfur coals. Therefore, it is likely that all coal-fired power plants constructed in the last half of the 1990s will include FGDs.

KEPCO reportedly plans to install a circulating fluidized bed combustion boiler in a plant that will use domestic anthracite (World Coal, 1993).

Government-funded KIER has undertaken a range of clean coal technology (CCT) research projects, and presently has a high level of scientific understanding of the array of CCT options. However, present indications are that CCTs for power plants will be largely imported or licensed from foreign manufacturers.

\section{PRIVATE SECTOR OPPORTUNITIES}

The government's 1993 economic plan sets out goals to reduce government regulations and to encourage private sector participation in the power sector. The last half of the 1990s are expected to be characterized by a gradual opening of the non-nuclear power sector to private sector investments. However, foreign equity participation is likely to be limited to less than 50 percent for each project in the 1990s.

During the next two decades, capital investments of US\$80-100 billion are projected for generation capacity, excluding distribution costs. These high investment needs and the Korean government's recent policy moves to allow private power, suggest growing opportunities in this large power market. For the next decade, estimates of private power opportunities range up to $6,000 \mathrm{MW}$ with the first projects likely to be 1,800 MW (800 MW gas-fired and 1,000 coal-fired). It is important to note that an independent power producer (IPP) industry has yet to develop, and that some delays in introducing IPPs are expected.

KEPCO has made substantial efforts to reduce the costs of generating electricity through fuel substitution, and by building larger and more efficient power plants. However, KEPCO's rate 
of return on investment has decreased from 12 to 8 percent-well below levels attractive to private foreign investors. Independent power plants will probably need to operate at high capacity factors to achieve acceptable returns on investments. The high percentage of nuclear and coal-fired capacity in the Korean grid may make it more difficult for IPPs to achieve the high capacity factors that they will want. This combined with uncertainty about timely rate increases is expected to moderate the development of a flourishing IPP sector in the near future.

\section{Sources of Information and References}

Asia 1994 Yearbook, 1994. Far Eastern Economic Review, ed. Robert Delfs, Review Publishing Company, Ltd., Hong Kong.

Asian Development Outlook 1994, Asian Development Bank. Oxford University Press, Hong Kong.

BP Statistical Review of World Energy, 1994. The British Petroleum Company, England, June.

Coal in Asia-Pacific, 1994. Tables 2-1 - 2-7.

NEDO (New Energy and Industrial Technology Development Organization), Tokyo, January, vol. 5, no. 3, pp. 55-57.

Electric Utilities Data Book for the Asia and Pacific Region 1993, 1993. Asian Development Bank, Manila, January.

Independent Power Report, 1994. ed. Kathy Carolin Larsen, McGraw-Hill, New York, December 2.

KEEI, 1995. 1995 Korea Energy Outlook, Korea Energy Economics Institute, Korea, January.

KEPCO Annual Report, 1994. Korea Electric Power Corporation.

Khartukov, Eugene, 1994, "Russian Far East Emerging as Significant Gas Supplier," Pipeline \& Gas Journal, Dallas, August.
Kim Il-Kwang, 1994, "Coal Demand Outlook and Concerned Policy in Korea," Presented at APEC Coal Flow Seminar, Tokyo, October 4-6.

King's International Coal Trade, 1992. King Publishing Corporation, Knoxville, Tennessee.

Korea Energy Review Monthly, 1993. Coal Statistics, Tables III-1 - III-5, Korea Energy Economics Institute, Korea, February, pp. 64-68.

Korea Energy Review Monthly, June, pp. 62-66

Korea Energy Review Monthly, Oct/Nov, pp. 65-68.

Korea Energy Review Monthly, 1994. March, pp. 59-62.

Korea Overseas Information Service, 1990. A Handbook of Korea, Samhwa Printing Co., Ltd., Seoul, 574 pp.

Lee Hoesung, 1993. "South Korea: Tasks for Environmentally Sound and Sustainable Development," Korea Energy Review Monthly, Korea Energy Economics Institute, Korea, November.

Lee Won-Woo, 1994, "Coal Demand Outlook and its Policy Implication," Coal in Asia Pacific, NEDO, Tokyo, March, Vol. 5 No. 4.

Long-Term Power Supply and Demand Plan: 1991-2006, 1991. Ministry of Energy and Resources (of Korea) November.

Major Statistics of Korean Economy, August, 1994. National Statistical Office, Korea.

Paik Keun-Wook, 1992, "Towards a Northeast Asia Energy Charter," Energy Policy, Oxford, United Kingdom, May.

Power in Asia, 1995. ed. Frank Gray, Financial Times Energy Publishing, London, February 20.

Prime Minister's Decree on the Air Quality Protection Law, 1992, Korea, August.

World Coal, 1993, "Moving Towards the Millennium," United Kingdom, September, pp. 22-24. 


\section{East-West Center}

The U.S. Congress established the East-West Center in 1960 as a private academic research institution. The Center's goal is to foster mutual understanding and cooperation among governments and peoples of the Asia-Pacific region, including the United States. Principal funding for the Center comes from the U.S. government, with additional support provided by private agencies, individuals and corporations, and more than 20 Asian and Pacific governments.

The Center promotes responsible development and long-term stability for all economies of the region and helps prepare the United States for constructive involvement in Asia and the Pacific.

\section{PREM}

The Program on Resources: Energy and Minerals (PREM) conducts research in the two broad program areas of energy and minerals. Research focuses on energy resources (oil, coal, and gas) and non-fuel minerals in the Asia-Pacific region and the Western Hemisphere.

\section{Coal Project}

The Coal Project examines policies and economics of coal supply and consumption in Asian economies. Emphasis is on the power sector and the impacts of evolving government energy and environmental policies on future coal use. The project prepares long-term projections of coal production, consumption, and trade; coal-fired power plant capacity; and the rate of introduction of clean coal technologies in the Asia-Pacific region. The Coal Project advises the U.S. Department of Energy's Office of Fossil Energy, and is actively involved with the Asia Pacific Economic Cooperation Experts' Group on Clean Coal Technology. 